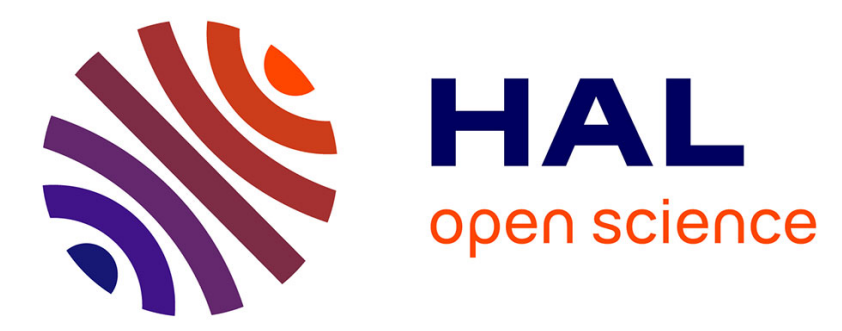

\title{
Transverse translunate fracture-dislocation: a rare injury
}

Sabri Mahjoub, Bertrand Dunet, Patricia Thoreux, Alain-Charles Masquelet

\section{To cite this version:}

Sabri Mahjoub, Bertrand Dunet, Patricia Thoreux, Alain-Charles Masquelet. Transverse translunate fracture-dislocation: a rare injury. Hand Surgery and Rehabilitation, 2016, 35 (3), pp.220-224. 10.1016/j.hansur.2016.02.008 . hal-02564102

\section{HAL Id: hal-02564102 https://hal.science/hal-02564102}

Submitted on 5 May 2020

HAL is a multi-disciplinary open access archive for the deposit and dissemination of scientific research documents, whether they are published or not. The documents may come from teaching and research institutions in France or abroad, or from public or private research centers.
L'archive ouverte pluridisciplinaire HAL, est destinée au dépôt et à la diffusion de documents scientifiques de niveau recherche, publiés ou non, émanant des établissements d'enseignement et de recherche français ou étrangers, des laboratoires publics ou privés. 


\title{
Transverse translunate fracture-dislocation: A rare injury
}

\section{Fracture-luxation translunaire transversale : une lésion exceptionnelle}

\author{
S. Mahjoub ${ }^{\mathrm{a}, \mathrm{c}}$, B. Dunet ${ }^{\mathrm{b}, \mathrm{c}, *}$, P. Thoreux ${ }^{\mathrm{a}}$, A.C. Masquelet ${ }^{\mathrm{a}}$ \\ ${ }^{a}$ Service de chirurgie orthopédique et traumatologique, hôpital Avicenne, 125, rue de Stalingrad, 93000 Bobigny, France \\ ${ }^{\mathrm{b}}$ Unité membre supérieur, service de chirurgie orthopédique et traumatologique, hôpital Pellegrin, place Amélie-Raba-Léon, 33076 Bordeaux cedex, France \\ ${ }^{ }$Service de chirurgie orthopédique et traumatologique, hôpital de Libourne, 112, rue de la Marne, 33505 Libourne, France
}

\begin{abstract}
Perilunate fracture-dislocation is rare. We report the case of a 24-year-old male who fell from his motorcycle and presented with a transverse lunate fracture with perilunate ligament damage. The initial diagnosis based on X-rays was confirmed by CT scan. A dorsal approach was used to obtain good reduction, double screw fixation and ligament reinsertion protected by temporary K-wires. To the best of our knowledge, this is the first case of transverse lunate fracture within perilunate fracture-dislocation. The patient returned to normal activities after 6 months.
\end{abstract}

Keywords: Carpus; Lunate; Dislocation; Fracture; Ligament

\section{Résumé}

Les fractures-luxations périlunaires du carpe sont rares. Nous rapportons le cas d'un homme de 24 ans, droitier qui, dans les suites d'une chute par accident de la voie publique en moto, a présenté une fracture-luxation translunaire avec atteinte ligamentaire périlunaire. Le diagnostic, suspecté sur les radiographies initiales, a été confirmé par un scanner. Un abord postérieur a été réalisé pour permettre une réduction de la fracture fixée par un double vissage enfoui, associée à une réinsertion ligamentaire et brochage temporaire en protection. Il s'agit, à notre connaissance, du premier cas rapporté de fracture transversale du lunatum dans le cadre d'une fracture-luxation périlunaire. Le patient a pu reprendre ses activités dans un délai de 6 mois.

Mots clés : Carpe ; Lunatum ; Luxation ; Fracture ; Ligament

\section{Introduction}

Perilunate fracture-dislocations of the carpal bones are rare [1-3]. We will describe the first case involving a transverse fracture of the lunate with complex perilunate ligament damage.

\footnotetext{
* Corresponding author.

E-mail address: bertrand.dunet@wanadoo.fr (B. Dunet).
}

\section{Case report}

This was a young man of 24 years who suffered trauma to both wrists following a motorcycle accident in September 2009. The initial examination found painful swelling of both wrists associated with total functional disability and pain during passive motion of the fingers with no sensory or motor neurological deficit, vascular damage or skin disorder.

The initial radiological assessment performed in the emergency room revealed a perilunate fracture-dislocation of the left wrist and a lunotriquetral separation with static volar axial misalignment of the intermediate segment (VISI) of the 
right wrist (Figs. 1 and 2). Specialized advice was sought, and after rereading the initial x-rays, a CT scan was performed to confirm the diagnosis of transverse lunate fracture in the left wrist associated with a comminuted intra-articular fracture of the radial styloid process and a fracture of the ulnar styloid process (Figs. 3 and 4). The CT scan also confirmed the dorsal displacement of the distal fragment of the lunate and the integrity of the articular lunocapitate surfaces.

Because of the observed displacement, we decided to perform urgent surgical treatment. Treatment consisted of a dorsal approach with capsulotomy according to Berger et al.
[4], combining compression of the bone block with flat head screws for the lunate and reduction of the articular surface of the radial styloid process under visual control. Surgical exploration confirmed the scapholunate and lunotriquetral ligament tears. Ligament reattachment with a Mitek $^{\mathrm{TM}}$ microanchor was performed and the repair was protected by temporary K-wire pinning in the left wrist (Fig. 5). The ulnar styloid process fracture was not fixed because the distal radioulnar joint in the left wrist was not unstable.

The patient used a simple wrist splint for 45 days. Active mobilization of the metacarpophalangeal and interphalangeal

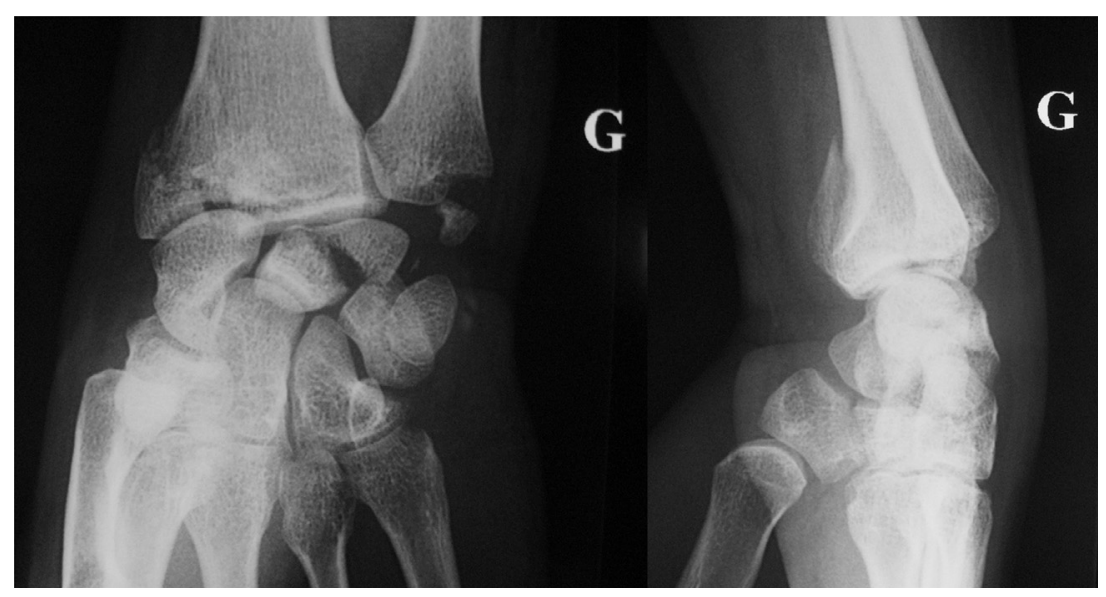

Fig. 1. Standard preoperative A/P and lateral radiographs of the left wrist.

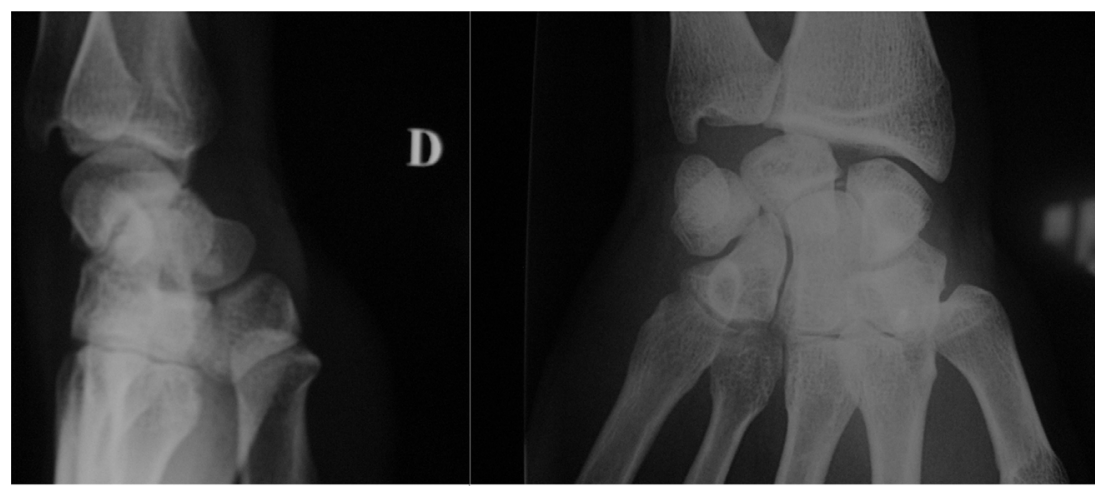

Fig. 2. Standard preoperative $\mathrm{A} / \mathrm{P}$ and lateral radiographs of the right wrist.

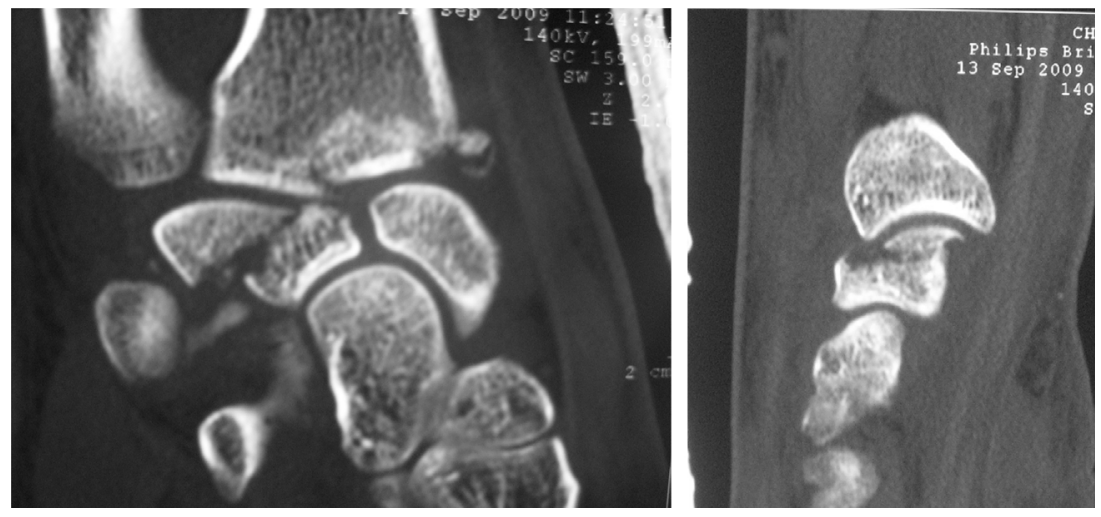

Fig. 3. Initial CT scan with frontal and sagittal sections showing the lunate and radius fractures. 

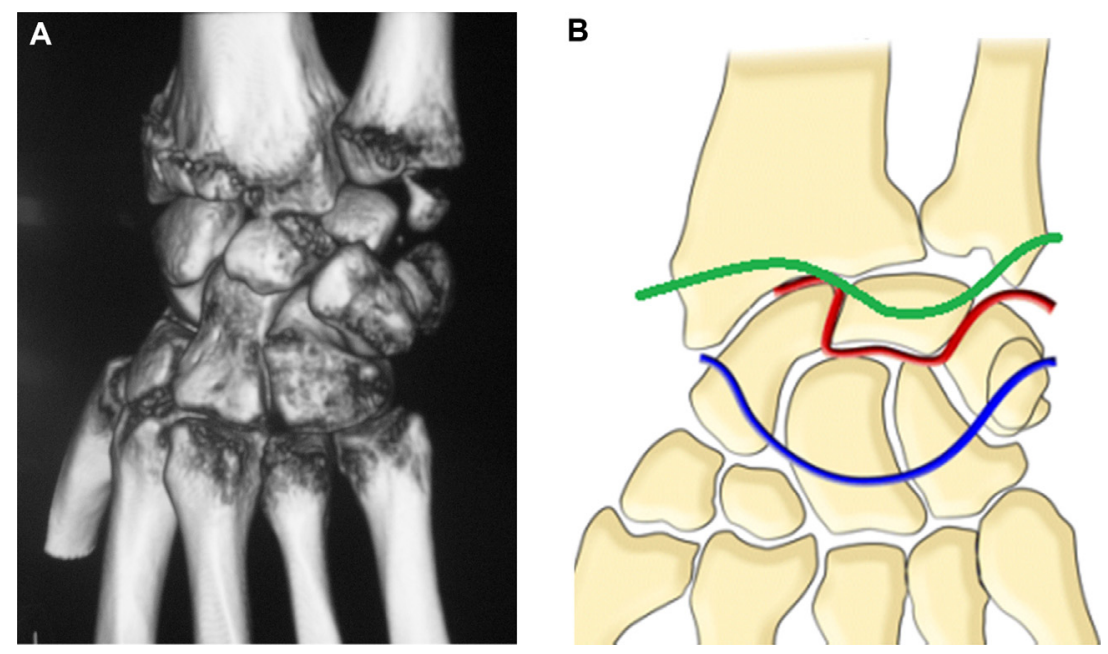

Fig. 4. Initial CT with 3D reconstruction (A). Diagram of the injury arcs described by Bain (B): green line: translunate arc; red line: small arc; blue line: large arc.

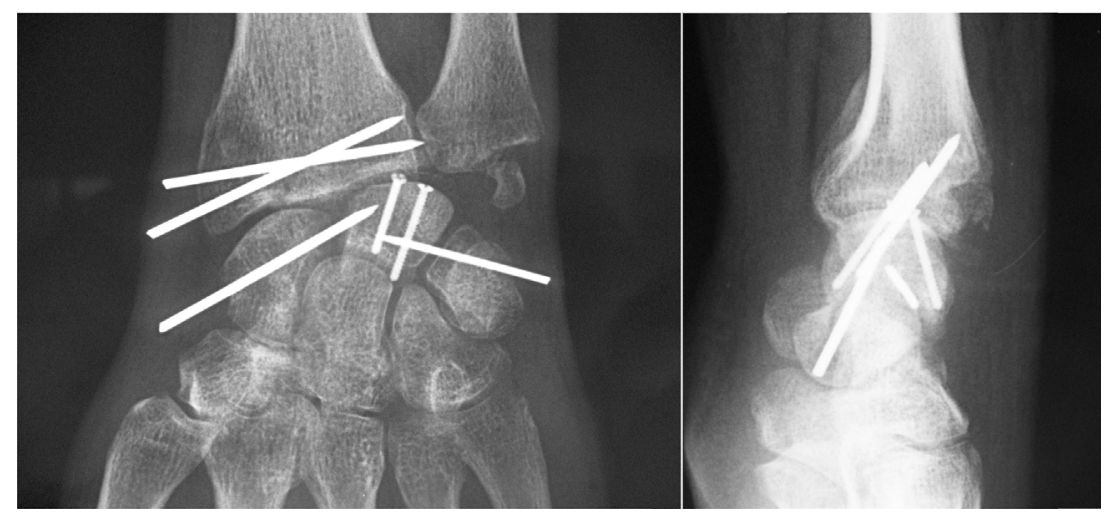

Fig. 5. Standard intraoperative A/P and lateral radiographs of the left wrist.

joints was allowed during the immediate postoperative period. Union of the bone fractures was confirmed at 6 weeks and the $\mathrm{K}$-wire was removed during outpatient surgery.

At the 1-year follow-up, the patient has regained all of his range of motion symmetrically with $70^{\circ}$ in extension, $60^{\circ}$ in flexion, $30^{\circ}$ in ulnar deviation and $15^{\circ}$ in radial deviation; he had no specific limitations in his activities. He had a PRWE total score of 8/100 [5] and a grip strength of $45 \mathrm{~kg}$ on a Jamar dynamometer in the right hand and $40 \mathrm{~kg}$ in the left hand [6]. No aseptic necrosis of the lunate was observed during the final assessment of the left wrist (Figs. 6 and 7).

\section{Discussion}

Malgaigne was the first to describe perilunate fracturedislocation in 1855 [7]. Lunate fractures represent $2 \%$ to $3.9 \%$ of all carpal fractures $[2,8]$ and occur in combination with perilunate fracture-dislocation in 5\% to $7 \%$ of wrist injuries [7,9]. Perilunate fracture-dislocation usually occurs among men between 20 and 30 years of age following a fall from a significant height or in a motor vehicle accident involving high kinetic energy [10]. Predominantly, perilunate dislocations are dorsal with only $3 \%$ being volar [10]. Conway et al. reported
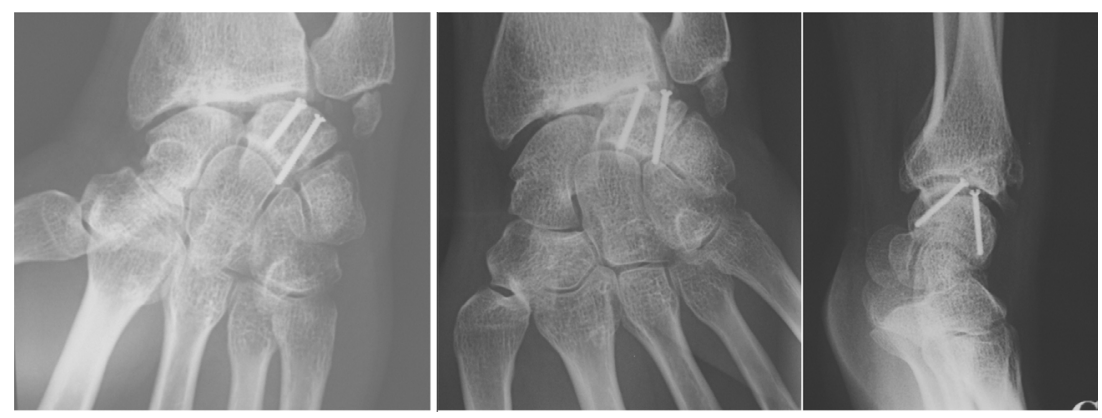

Fig. 6. One year control radiographs with $\mathrm{A} / \mathrm{P}$ view of radial deviation, A/P view of ulnar deviation and lateral view of the left wrist. 


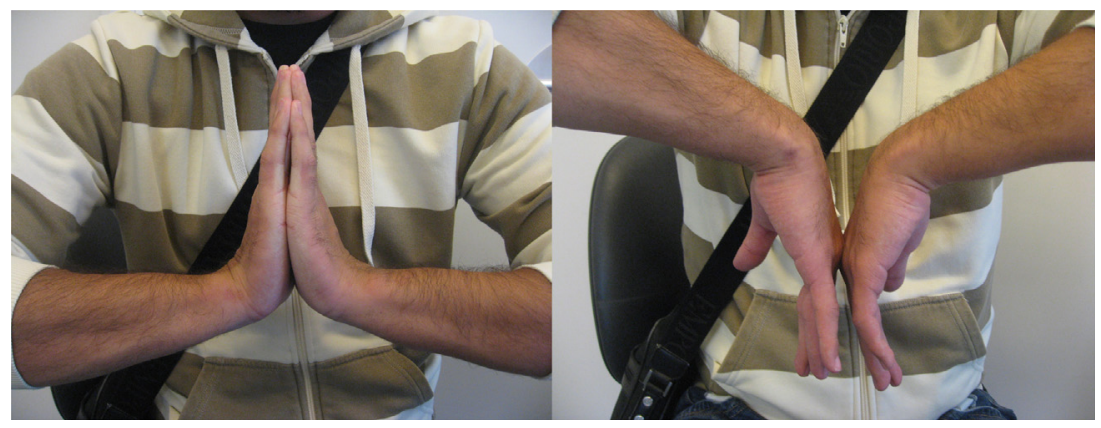

Fig. 7. Comparative clinical outcome in flexion and extension after 1 year.

three cases of volar translunate fracture-dislocation in 1989 [11]. In 2008, Lavelle et al. reported one case of coronal lunate fracture associated with ligament damage [12]. It is only in 1988 that a true transverse fracture, isolated from the lunate, was reported [13]. Yakoubi et al., in 2007, reported a frontal lunate fracture with dislocation of the perilunate [14]. Bain et al. reported several cases of frontal translunate fracturedislocation, but none were transverse [3]. During our literature search, we found no case with an injury combination like the one described here (Table 1).

Our hypothesis is that our patient was subjected to a movement combining extension, supination and ulnar deviation. We believe our patient initially placed his hands on the hypothenar eminence in hyperextension and ulnar deviation of the wrist, causing the scaphoid and the lunate to flex and leaving the triquetrum in abnormal extension. This led to breaking of the lunotriquetral joint and that trauma was followed by hyperextension and radial translation that caused the scapholunate ligament tear and the radius fracture $[15,16]$. This is a transverse shear mechanism of injury. Mayfield et al. described the mechanism of perilunate dislocation, suggesting that injuring forces spread around the lunate but not through it, which is contrary to our case [17]. This is how Johnson described the damage to the first and second Gilula carpal arcs according to Bain (Fig. 4, red and blue line) [18]. Like Bain et al., we believe that lesions of the translunate arc must be added (Fig. 4, green line) $[3,16]$. Unlike Bain et al., we do not believe that capitate impaction on the lunate is the origin of the fracture; instead there is hyperextension with the forearm

Table 1

Summary of cases of translunate fracture-dislocations.

\begin{tabular}{lcl}
\hline Authors & Number of cases & Lunate fracture type \\
\hline Teisen and Hjarbaek [13] & 1 & Transverse (type IV) \\
Conway et al. [11] & 3 & Scaphoid frontal damage \\
Amavarati et al. [8] & 1 & Sagittal \\
Yakoubi et al. [14] & 1 & Frontal \\
Lavelle et al. [12] & 1 & Frontal \\
Briseño and Yao [20] & 1 & Frontal \\
Bain et al. [16] & 22 & Frontal \\
Akane et al. [9] & 1 & Frontal \\
Our study & 1 & Transverse with perilunate \\
& & ligament damage without \\
& & scaphoid lesion \\
\hline
\end{tabular}

extending from supination and pronation, leading to a transverse translation from the ulnar side to the radial side [19]. Our case could be classified as a variant of the translunar fracture-dislocation on an intact scaphoid with dorsal displacement (Fig. 8) [10].

The diagnosis is based on clinical examination and standard radiographs. CT scan must be performed if there is any doubt, in order to avoid a delay in diagnosis [1,2]; this ensures better planning of the procedure by avoiding intraoperative discovery of a fracture [20]. The CT scan can determine the type of fractures, their displacement and reveal any associated ligament injuries.

Treatment uses a dorsal approach to reduce the intraarticular fracture of the lunate and reduce the scapholunate and lunotriquetral diastasis by ligament reattachment and temporary K-wire pinning. In 2008, Firth and Aden recommended a dual dorsal/volar approach to reattach the dorsal scapholunate and volar lunotriquetral ligaments [21]. Despite the severity of the initial injury, no osteonecrosis of the lunate was observed [9]. Early lunate fixation is likely to reduce this risk $[9,11]$.

Unlike some authors [9], we have not yet used arthroscopy in the care of these complex fracture-dislocations of the carpus affecting the proximal and distal carpal rows. Some of the potential advantages of arthroscopy are:

- comprehensive assessment of ligament damage, namely the intrinsic, extrinsic and cartilaginous ligaments;

- reduction in the size of the surgical incision, thereby postoperative stiffness;

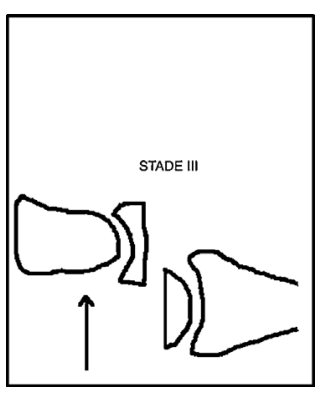

Fig. 8. Alternative mechanism in the Herzberg classification: translunate fracture-dislocation of intact scaphoid and stage III dorsal displacement. 
- help determine the mechanism of injury and thereby propose a specific treatment [22]. The use of arthroscopy can also be considered for an isolated fracture of a bone in the proximal row [22-24]. It does not seem appropriate to use proximal row carpectomy as first-line treatment [14,25-27].

\section{Conclusion}

Our case is the first reported case of a transverse fracture of the lunate as part of a translunar fracture-dislocation with lunotriquetral and scapholunate damage. The injury mechanism confirms the translunate arc hypothesis. CT scan should be performed when the initial diagnostic is uncertain in order not to delay the treatment. The fracture must be perfectly reduced and requires - in our opinion - a surgical approach that allows for screw insertion and ligament repair to obtain satisfactory functional results.

\section{Disclosure of interest}

The authors declare that they have no competing interest.

\section{References}

[1] Suh N, Ek ET, Wolfe SW. Carpal fractures. J Hand Surg Am 2014;39:785-91.

[2] Hey HW, Chong AK, Murphy D. Prevalence of carpal fracture in Singapore. J Hand Surg Am 2011;36:278-83.

[3] Bain GI, Pallapati S, Eng K. Translunate perilunate injuries - a spectrum of this uncommon injury. J Wrist Surg 2013;2:63-8.

[4] Berger RA, Bishop AT, Bettinger PC. New dorsal capsulotomy for the surgical exposure of the wrist. Ann Plast Surg 1995;35:54-9.

[5] MacDermid JC, Turgeon T, Richards RS, Beadle M, Roth JH. Patient rating of wrist pain and disability: a reliable and valid measurement tool. J Orthop Trauma 1998;12:577-86.

[6] Mathiowetz V, Weber K, Volland G, Kashman N. Reliability and validity of grip and pinch strength evaluations. J Hand Surg Am 1984;9:222-6.

[7] Kaewlai R, Avery LL, Asrani AV, Abujudeh HH, Sacknoff R, Novelline RA. Multidetector CT of carpal injuries: anatomy, fractures and fracturesdislocations. Radiographics 2008;28:1171-84.

[8] Amavarati RS, Saji MJ, Rajagopal HP. Greater arc injury of the wrist with fractured lunate bone: a case report. J Orthop Surg (Hong Kong) 2005; 13:310-3.

[9] Akane M, Tatebe M, Iyoda K, Ota K, Iwatsuki K, Yamamoto M, et al. Partial necrosis of the lunate after a translunate palmar perilunate fracturedislocation. Nagoya J Med Sci 2014;76:211-6.
[10] Herzberg G, Comtet JJ, Linscheid RL, Amadio PC, Cooney WP, Stalder J. Perilunate dislocations and fracture-dislocations: a multicenter study. J Hand Surg Am 1993;18:768-79.

[11] Conway WF, Gilula LA, Manske PR, Kriegshauser LA, Rholl KS, Resnik C. Translunate, palmar perilunate fracture - subluxation of the wrist. J Hand Surg Am 1989;14:635-9.

[12] Lavelle WF, Whipple R, Uhl R. Translunate transradial styloid fracturedislocation: a case report (a rare translunate fracture-dislocation). Injury 2008;39:359-63.

[13] Teisen H, Hjarbaek J. Classification of fresh fractures of the lunate. J Hand Surg Br 1988;13:458-62.

[14] Yakoubi M, Meziani N, Yahia Cherif M, Kasbi A, Benbakouche R. Carpal dislocation combined with a lunate fracture. Report of a case of this new variety. Chir Main 2007;26:247-9.

[15] Garcia-Elias M. Lunotriquetral complex lesions: treatment principles. Chir Main 2003;22:57-64.

[16] Bain GI, McLean JM, Turner PC, Sood A, Pourgiezis N. Translunate fracture with associated perilunate injury: 3 case reports with introduction of the translunate arc concept. J Hand Surg Am 2008;33:1770-6.

[17] Mayfield JK, Johnson RP, Kilcoyne RK. Carpal dislocations: pathomechanics and progressive perilunar instability. J Hand Surg 1980;5: 226-41.

[18] Johnson RP. The acutely injured wrist and its residuals. Clin Orthop Relat Res 1980;149:33-44.

[19] Christodoulou L, Palou CH, Chamberlain ST. Proximal row transcarpal fracture from a punching injury. J Hand Surg Br 1999;24:744-6.

[20] Briseño MR, Yao J. Lunate fractures in the face of a perilunate injury: an uncommon and easily missed injury pattern. J Hand Surg Am 2012;37:63-7.

[21] Firth GB, Aden A. Treatment of lunate and perilunate dislocations with a combined approach and anchor repair of the dorsal scapholunate interosseous ligament. SA Orthop J 2008;32-8

[22] Van Overstraeten L, Camus EJ. A systematic method of arthroscopic testing of extrinsic carpal ligaments: implication in carpal stability. Tech Hand Up Extrem Surg 2013;17:202-6.

[23] Dana C, Doursounian L, Nourrissat G. Arthroscopic treatment of a fresh lunate bone fracture detaching the scapholunate ligament. Chir Main 2010;29:114-7.

[24] Slutsky DJ, Trevare J. Use of arthroscopy for the treatment of scaphoid fractures. Hand Clin 2014;30:91-103.

[25] Marzouki A, Almoubaker S, Hambi O, Laharch K, Boutayeb F. Transscaphoid perilunate dislocation with proximal displacement of the lunate and proximal scaphoid. A case report. Chir Main 2013;32:96-9.

[26] Huish Jr EG, Vital MA, Shin AY. Acute proximal row carpectomy to treat a transscaphoid, transtriquetral perilunate fracture-dislocation: a case report and review of the literature. Hand 2013;8:105-9.

[27] Razafimahandry HJC, Rakoto-Ratsimba HN, Gille O. Open transscaphoid perilunate dislocation with proximal displacement of the lunate and proximal scaphoid. Chir Main 2009;28:113-5. 